MAREK RUTKOWSKI

\title{
Weryfikacja urzęników państwowych w Królestwie Polskim po Powstaniu Listopadowym
}

\author{
Verifikation der Staatsbeamten \\ im Königreich Polen nach dem Novemberaufstand
}

1. Wprowadzenie. 2. Weryfikacja popowstaniowa urzędników państwowych. 3. Stan służby. 4. Wnioski.

1. Einleitung. 2. Verifikation der Staatsbeamten nach dem Novemberaufstand. 3. Stand des Dienstes. 4. Schlussfolgerungen.

1. W początkach ery paskiewiczowskiej, w procesie dalszego utrzymania odrębności państwowej i narodowej zniewolonego Królestwa Polskiego, niezwykłego znaczenia nabiera rola ówczesnych urzędników państwowych. W tej sytuacji przeprowadzenie weryfikacji urzędników wszystkich rang okazywało się dla rosyjskich władz oczywiste. Zagadnienie to nabierało dodatkowego znaczenia wobec faktu, iż na skutek dokonania licznych zmian personalnych kadry urzędniczej przez administracje powstańczą oraz działających jedynie na własną rękę rosyjskich dowódców wojskowych, wśród urzędników i oficjalistów Królestwa znalazł się po upadku Powstania Listopadowego spory odsetek osób ,nieporządanych”. Już manifesty cesarskie z 16 września i 15 listopada 1831 r. oraz postanowienie Rządu Tymczasowego z 24 października tegoż roku określiły nieważność awansów z okresu Powstania, a przede wszystkim precyzowały wstępnie warunki ponownego przyjęcia do służby oraz weryfikacji urzędniczej. Jednocześnie w Królestwie wprowadzono zatwierdzoną $w$ Petersburgu tabelę rang oraz listę stanów służby. Przepisy te, wzorowane na pierwowzorze rosyjskim, miały ułatwić kontrolę kadry urzędniczej Królestwa.

W efekcie prowadzona w Królestwie Polskim lat trzydziestych XIX w. weryfikacja urzędnicza nabierała form wielostopniowych, przy założeniu, iż wgląd w szczególowe akta personalne posiadały wszystkie jednostki administracyjne stanowiące miejsce zatrudnienia. Główny człon akcji nadzorczej 
realizowany był jednak na szczeblu ministerialnym (Komisji Rządowej), ze szczególnym uwzględnieniem roli Komisji Rządowej Spraw Wewnętrznych, Duchownych i Oświecenia Publicznego (KRSWDiOśP), traktowanej jako ministerstwo zatrudniające największą liczbę urzędników i oficjalistów. Na ministerstwo to nałożono obowiązek przedstawiania kompletnych list czynnych urzędników państwowych do okresowej oceny przez rząd krajowy - Radę Administracyjną.

Oceniając zachodzące w Królestwie Polskim wczesnej ery paskiewiczowskiej procesy weryfikacji i przyjmowania na posady urzędników i oficjalistów, należy zaznaczyć, iż przebiegały one nadzwyczaj sprawnie. Formalnie, realizując postulaty władz rosyjskich, wykluczono z szeregów administracji osoby „nieprawomyślne”, np. czynnie wspierające wladze powstańcze. KRSWDiOśP przeciwstawiała się jednak przyjmowaniu w szeregi polskiej kadry urzędniczej osób bez odpowiednich kompetencji. Okazuje się, iż do obrony administracji krajowej przed napływem czynowników rosyjskich przyczyniło się wprowadzenie w Królestwie szczegółowych przepisów dotyczących stanów shużby urzędniczej. Opisane ustawodawstwo miało eliminować ze służby element niepewny politycznie. W praktyce w znaczącym stopniu blokowało ono napływ do administracji Królestwa (pro)rosyjskich karierowiczów bez odpowiednich kwalifikacji. W efekcie polscy administratorzy potrafili wbrew intencjom rosyjskim wykorzystać prawodawstwo $\mathrm{w}$ sposób zgodny z interesami Królestwa. Było to działanie wykorzystujące utrzymywaną w okresie rządów paskiewiczowskich zasadę legalizmu. Dzięki takiemu postępowaniu polskich władz Królestwa Rosjanie mieli trudności we wprowadzaniu do polskich struktur rosyjskiego, najczęściej niepełnowartościowego elementu.

2. Wladze powstańcze prawie we wszystkich gałęziach służby publicznej dokonały zmian personalnych. $Z$ kolei rosyjskie władze wojskowe - zarówno w trakcie kampanii, jak i po jej zakończeniu - w wielu miejscach przeprowadziły własne nominacje na urzędników i oficjalistów Królestwa. Obydwie formy dzialań nie spotkały się jednak z uznaniem Komisji Rządowej Spraw Wewnętrznych (KRSW), która nie mogła "udzielić rękojmi” ani co do sposobu postępowania władz rewolucyjnych, ani co do kompetencji oraz posiadania stosownych prerogatyw nominacyjnych wojskowych władz rosyjskich ${ }^{1}$. Istnialo zresztą postanowienie Rządu Tymczasowego z dnia 24 października 1831 r., na mocy którego wszystkie awanse $\mathrm{z}$ czasu rewolucji uznano za nieważne ${ }^{2}$.

\footnotetext{
${ }^{1}$ Archiwum Główne Akt Dawnych w Warszawie, zespół II Rady Stanu Królestwa Polskiego 1833-1841 (dalej: II RS) 102/4.

${ }^{2}$ Archiwum Główne Akt Dawnych w Warszawie, zespół Rady Administracyjnej Królestwa Polskiego 1815-1867 (dalej: RA) 23/62-64.
} 
Ostatecznie Komisja Rządowa Spraw Wewnętrznych podjęla akcję weryfikacji nadań nominacyjnych, rozpoczynając ją od zbierania wszelkich wiadomości na ten temat, przy równoczesnej realizacji zaleceń rządowych zmierzających do określenia warunków i (następnie, po weryfikacji) potwierdzenia ewentualnego przyzwolenia na zachowanie przez urzędników stanowisk. Wprowadzono tu zastrzeżenie, iż sytuacja taka może ulec zmianie ze względu na tzw. ważne powody, których charakteru przezornie nie określono ${ }^{3}$. Powołano też specjalny Komitet do Kwalifikacji (Rozkwalifikowania) Urzędników Cywilnych Królestwa Polskiego ${ }^{4}$.

W zakresie owej weryfikacji obowiązywały dwa postanowienia carskie: 1) manifest z 4/16 września 1831 r., na mocy którego wezwano do ponowienia przysięgi dla dynastii Romanowych wszystkich mieszkańców Królestwa (w tym oczywiście i wszystkich obywateli zajmujących posady urzędników i oficjalistów)

${ }^{3}$ II RS $102 / 4$.

${ }^{4} \mathrm{O}$ pracach tego Komitetu: RA 21/434-436; RA 22/187-188, 446-449; RA 23/360, 597-598, 649-650, 807-808; RA 24/54-55, 265-266, 314-317, 840, 844-846; RA 25/366-367, 550-551; RA 26/58-59, 549-550; RA 27/831-833; RA 22/212-213. Na czele Komitetu do Klasyfikacji Urzędników stanął $w$ początkach stycznia 1832 r. radca stanu Józef Kalasanty Szaniawski. 3 II 1832 r., podczas 30 . sesji Rządu Tymczasowego, na członków tegoż Komitetu mianowano: byłego inspektora generalnego Uniwersytetu Warszawskiego Krzyżanowskiego (z ramienia KRWRiOśP), sędziego sądownictwa najwyższej instancji Lubieńskiego (z ramienia Komisji Rządowej Sprawiedliwości), referendarza stanu Jaźwińskiego (z ramienia Komisji Rządowej Spraw Wewnętrznych i Policji), referendarza stanu Bobrowskiego (z ramienia Komisji Rządowej Przychodów i Skarbu). Dodatkowo na zastępców mianowanych już członków Komitetu wybrano 3 II 1832 r., zachowując [...] możność powolywania rzeczonych czlonków w razie uznanej potrzeby: profesora Uniwersytetu Warszawskiego Engekla, sędziego najwyższej instancji Faleńskiego, referendarza stanu Dunina oraz radcę stanu Bolestę. Projekt wewnętrznej organizacji Komitetu do Klasyfikacji Urzędników został opracowany przez radce stanu Szaniawskiego, a następnie przedstawiony do akceptacji Rady Administracyjnej w specjalnym raporcie z 26 IV 1832 r. Ta ostatnia instytucja projekt organizacyjny zatwierdziła 4 V 1832 r., podczas swojej 12. sesji, z tem atoli nadmienieniem, że oznaczona $w$ pomienionym projekcie ilość posiedzeń na dwa $w$ tygodniu znalazla [RA] niedostatecznq, i że z tego powodu, $w$ zamiarze wyrzeczenia jak najrychley końca czynności pomienionego Komitetu, mieć chce ażeby czlonkowie jego zbierali sie przynajmniej cztery razy $w$ tydzień

${ }^{5}$ O ponowieniu przysięgi na rzecz cara: RA 20/68-72, 279, 421, 708-709; RA 21/356-358; RA 22/401-403; RA 25/516-517; Dziennik Urzẹdowy Województwa Mazowieckiego (dalej: DUWM) - pismo Komisji Województwa z 24 XI 1831 r. Działo się tak głównie dlatego, iż 25 I 1831 r. Mikołaj I został w Królestwie Polskim oficjalnie zdetronizowany, o czym: W. B ortnowski, W sprawie aktu detronizacji Romanowów ze stycznia 1831 r., „Przegląd Historyczny" 1959, t. 50; W. Zaj ew ski, Zabiegi "Nowej Polski" o detronizacje Romanowów $w$ styczniu 1831 r., „Zeszyty Naukowe Uniwersytetu Lódzkiego”, Nauki Humanistyczno-Społeczne" 1958, z. 8; te nże, Koronacja $i$ detronizacja Mikolaja I w zamku Królewskim, „Przegląd Humanistyczny” 1971, nr 5. 
2) rozporządzenie określające, iż do dawniej sprawowanych urzędów zostanq przywróceni [jedynie] wszyscy ci, którzy przed dniem 15 listopada $1831 \mathrm{r}$. powrócq do swoich obowiazków ${ }^{6}$.

Jeszcze jednak w swoim raporcie opisującym powyższe działania, a spisanym w roku 1834, KRSWDiOśP przyznała, iż wykonanie ostatniego z dwu wymienionych rozporządzeń okazało się dla aparatu państwowego relatywnie trudne; przyczyny tego były dwie:

a) nagminne przedstawianie przez urzędników zaświadczeń o „niemożności” stawienia się do pracy w urzędzie na wyznaczony przez władze ostateczny termin ( $\mathrm{tj}$. do 15 listopada 1831 r.);

b) częste przejmowanie danego urzędu przez nominatów działających $z$ nadania wojskowej władzy rosyjskiej'.

W tej sytuacji postanowiono dokładnie zweryfikować całą pozostającą w czynnej shużbie kadrę urzędniczą Królestwa, przez prześledzenie jednostkowych akt personalnych. KRSW, realizując otrzymane polecenia, przedstawila zatem 26 maja 1832 r. do oceny Radzie Administracyjnej (RA) kompletne listy personalne czynnych urzędników Królestwa Polskiego. Spis ten podzielono na trzy części, klasyfikując urzędników państwowych według trzech kategorii ${ }^{8}$.

Formalnie jednak w Królestwie Polskim ery popowstaniowej wprowadzono klasyfikację urzędniczą zatwierdzoną przez członka Rządzącego Senatu - Nowosilcowa oraz asygnowaną przez Ministra Sekretarza Stanu do Spraw Królestwa Polskiego - Stefana hr. Grabowskiego9. Stosownie do ustanowionej klasyfikacji obsadzano też wszystkie zwolnione posady urzędnicze. Komisja Rządowa Spraw Wewnętrznych, Duchownych i Oświecenia Publicznego

${ }^{6}$ II RS 102/4-5. O innych, mniej znaczących, zasadach obowiązujących przy weryfikacji: RA 23/138-143; RA 24/517, 594-604; RA 26/656.

?II RS $102 / 4-5$.

${ }^{8}$ II RS $102 / 5$ i dalej. Tych szczegółowych wewnętrznych zasad podziału klasyfikacji urzędniczej $w$ aktach ministerialnych jednak nie przedstawiono; RA 22/212. W zapisie protokołu posiedzenia Rządu Tymczasowego $\mathrm{nr} 38 \mathrm{z} 2$ III 1832 r. odczytano odezwę feldmarszałka Paskiewicza nr 22/295 z 5 II 1832 r., przedstawiającą odpowiednie polecenie Mikołaja I, gdzie czytamy, iż było wolq Najjaśniejszego Pana ażeby nadestane zostaly Jego Cesarsko-Królewskiej Mości listy imienne urzędników Królestwa, należqcych do pięciu kategorii Kategorie te zostaly okresilone przez wspomnianą odezwę Paskiewicza $z$ wylqczeniem wszakże niższych stopni, jako to: kancellistów, woźnych, burmistrzów pomniejszych miasteczek, strażników komór, itp. Ponieważ urzędników państwowych wyższej kategorii niż trzecia w Królestwie Polskim wczesnej epoki paskiewiczowskiej praktycznie nie było, należy stąd wnosić, iż rozporządzenie to dotyczyło osób zakwalifikowanych do kategorii - od trzeciej do siódmej włącznie. RA 25/365-366, RA 26/58-59, 549-550; RA 27/831-832. Z przedstawianych przez Komitet do Klasyfikacji Urzędników skierowywanych do Rady Administracyjnej sprawozdań wynika, iż najczęściej sporządzano listy urzędników zaliczanych do kategorii trzeciej oraz czwartej.

${ }^{9}$ II RS 101/74-102. 
przyznawała, iż dokonana klasyfikacja i weryfikacja pozostawiała praktycznie jeszcze w roku 1834 wiele do życzenia. Konstatacja tego faktu mobilizowała wówczas do przeprowadzania bardzo dokładnej weryfikacji nowo przyjmowanych urzędników, a także do wprowadzenia ciągłego nadzoru ich postępowania, a nawet „usposobienia”. Założenie to realizowano $\mathrm{m}$. in. poprzez wprowadzenie nakazu nadsyłania do warszawskiej centrali tzw. stanów służby poszczególnych urzędników. Obiecywano sobie, iż takie właśnie postępowanie doprowadzi do całkowitej realizacji założeń rządowych, dotyczących nadzoru i klasyfikacji kadry administracyjnej Królestwa ${ }^{10}$.

Komisja Rządowa SWDiOśP wyrażała w roku 1834 przekonanie, iz sukces prac administracji państwowej w pełni zależy od sposobu postępowania władz wykonawczych. Zgodnie z opinią ministerialną, władze wykonawcze miały w tym względzie postępować czynnie i sprężyście. Stąd też zwracano szczególną uwage nie tylko na dostarczanie wszelkich niezbędnych środków do funkcjonowania służby publicznej, lecz także na zastosowanie odpowiedniego nadzoru urzędników i oficjalistów. Nabór miał dotyczyć tylko tych osób (innych w ogóle nie przyjmowano do służby), które można było uznać za sprawdzalne pod względem: a) przywiązania do tronu, b) moralnego postępowania, c) zdolności osobistych, d) znajomości praw i struktury administracyjnej Królestwa.

Przy doborze urzędników KRSWDiOśP postępowała wówczas zgodnie ze wskazówką przekazaną przez RA, gdzie dokonano podziału urzędników na poszczególne kategorie ${ }^{11}$. Stosując taką metodę działania, $w$ toku przeprowadzonych $w$ ciągu roku 1834 prac weryfikacyjnych $w$ administracji cywilnej osiągnięto następujące efekty. W tym czasie:

1) zwolniono $z$ zajmowanych stanowisk 20 urzędników, określając ich jako osoby nie cieszące się zaufaniem ze strony władz rządowych (liczba ta jest zdecydowanie niewielka);

2) przedstawiono do pensji emerytalnej (ze względu na wiek, osłabione zdrowie, względnie niedobór klasyfikacji) 34 osoby;

3) wprowadzono do służby 17 urzędników, którzy nie brali czynnego udziału w dzialaniach rewolucyjnych;

4) przeniesiono (na polecenie Namiestnika wydane w drodze łaski) z urzędniczej kategorii trzeciej do kategorii drugiej 31 osób; wszystkie one zostały umieszczone na jakichś urzędach.

Komisja Rządowa SWDiOśP oświadczała w połowie lat trzydziestych, iż jednym z priorytetów jej działań było wprowadzenie większego nadzoru

${ }^{10}$ II RS102/5 i dalej.

11 II RS 103/3; II RS 101/74-102. Znajduje się tu tzw. "klasyfikacja tabellaryczna”" urzędników państwowych. 
nad dzialalnością administracji publicznej oraz zapewnienie sobie prawego sposobu myślenia nawet tych urzędników, którzy ewentualnie w przyszłości dopiero zajmowaliby posady rządowe. Dążąc do realizacji tych zamierzeń, KRSWDiOśP poleciła, aby już przy przyjmowaniu na aplikację (w charakterze aplikantów) przy którymś z wydziałów administracji podlegających tej wlaśnie Komisji, wymagano udzielenia na to zgody przez samo ministerstwo. Zgoda taka mogła być wydana dopiero po przeanalizowaniu jednostkowych opinii nadsyłanych przez Komisje Wojewódzkie. Wnioski te z kolei miały być poparte przez Naczelników Wojennych - miały zawierać opinie co do spokojnego zachowania sie (podczas powstania) oraz dobrej konduity kandydata $^{12}$.

W raporcie KRSWDiOśP za rok 1835, w części dotyczącej Wydziału Administracji Ogólnej, Komisja przedstawiła dokładnie zakres prerogatyw i wytycznych realizowanych $w$ tym czasie przy obsadzaniu wakujących posad oraz dotyczących warunków umieszczania na posadach ubiegających się o nie osób. Okazało się, iż przy realizacji tych zasad usunięto wszelka niepewność w kwestii weryfikacji urzędników, określanych jako lojalnych, inaczej mówiąc: zaslugujących na zaufanie rzqdu. Opierając się na tej zasadzie, w roku 1835 oddalono ze służby osiem osób i wprowadzono na ich miejsce 18 nowych urzędników. Jednocześnie też wówczas nadal przekwalifikowywano urzędników, co weryfikował zresztą bezpośrednio Paskiewicz. Otóż podnoszono - jak poprzednio - ich formalne kwalifikacje przez przeniesienia przez Namiestnika $w$ drodze laski, dokonywane najczęściej na poziomie przesunięcia $\mathrm{z}$ grupy trzeciej do drugiej. Proceder ten w roku 1835 dotyczył 42 osób. W tym samym okresie KRSWDiOśP przedstawiła do pensji emerytalnej 12 osób $\mathrm{z}$ administracji cywilnej, motywując swoje wnioski złym stanem zdrowia wymienionych urzędników ${ }^{13}$.

Nowych urzędników i oficjalistów KRSWDiOśP $\mathrm{z}$ zasady wybierała $z$ listy kandydatów, jednak zwracała przy tym uwagę, iż bardzo często (jak władze administracyjne przekonywaly się o tym $w$ drodze doświadczenia) nie spełniali oni wymogów stawianych osobom przygotowującym się do pełnienia obowiązków służby publicznej. Wyciągano $\mathrm{z}$ tego wniosek, że jakkolwiek poprzednio wykazane przez niejednego $\mathrm{z}$ kandydatów ,zasługi”, predestynujące do zajmowania posad państwowych, przynosily ze sobą konieczność wpisania go na listy kandydatów, nie powinno to jednak - w opinii KRSWDiOśP - zwalniać władz rządowych od konieczności poddawania nawet teoretycznie najbardziej ,zasłużonych" kandydatów egzaminowi, przewidywanemu dla wszystkich osób ubiegających się o posady państwowe (egzaminy na kandydatów na stanowiska rządowe wprowadzono w czasach Księstwa War-

\footnotetext{
${ }^{12}$ II RS 103/3-4.

${ }^{13}$ II RS $104 / 2-3$.
} 
szawskiego, jeszcze w 1808 r.). Komisja Rządowa SWDiOśP starała się w ten sposób odciąć od relatywnie często wówczas praktykowanego przez rosyjskie czynniki decyzyjne zwyczaju przekazywania stanowisk w słuźbie państwowej osobom zupełnie do tego nieprzygotowanym, które dostawały się na te urzędy tylko na podstawie tzw. ,zashug" rozumianych jako zasługi wykonywane dla (wojskowej) władzy rosyjskiej. Formalnie chodziło jednak o to, aby osoby powoływane do pracy nie zawodzily oczekiwań rzqdu przede wszystkim pod względem profesjonalizmu. Stąd też wypływal dla KRSWDiOśP wniosek, iż na listę kandydatów na urzędników państwowych można było wpisywać tylko te osoby, które udowodnią swoje kwalifikacje przechodząc przez sito egzaminacyjne. Komisja Rządowa SWDiOśP zaznaczała jednak w $1834 \mathrm{r}$. - wypowiadając się przeciw tym wnioskom - iż można było stosować odstępstwo od zasady egzaminowania przyszlych urzędników państwowych w sytuacji, gdy dana osoba uzyskiwała taki przywilej ze strony władz rządowych $w$ drodze laski. Pozostawiano tu zatem furtkę dla swobodnej decyzji władzy rosyjskiej ${ }^{14}$.

Realizując zamiar profesjonalnej weryfikacji wszystkich osób starających się o urzędy państwowe, KRSWDiOśP przygotowała ostatecznie w $1835 \mathrm{r}$. projekt odpowiedniej ustawy, który przesłano do zaopiniowania Komisji Rządowej Sprawiedliwości. Uznano przy tym, iż po zatwierdzeniu przez wladze centralne przedstawionego przez KRSWDiOśP projektu nastąpi raz na zawsze ustalenie porzqdnego biegu slużby publicznej. Zarząd KRSWDIOśP podnosił przy tym, iż urzędnik zdatny $i$ prawy, pojqwszy ducha rzadu, jego zamiary poznawszy oraz miejscowe kraju potrzeby, tak potrafi pogodzić obowiqzki swoje, że i slużba nie dozna zawodu, i rzadzeni znajdq $w$ nim opieke, jaka sie im $z$ prawa należy. Krytykowano tym samym: nieznajomość prawa lokalnego widoczną wśród napływowych urzędników rosyjskich, oraz widoczne uchybienia w postępowaniu urzędników

${ }^{14}$ Loc. cit. O pragmatyce urzędniczej $w$ początkach okresu paskiewiczowskiego $\mathrm{m}$. in.: RA 20/8, 20-22, 33-29, 44-62, 81-82, 86-87, 116-117, 128-136, 215-216, 256-260, 261-264, $265-267,314-315,340-341,342-343,364-365,423-424,436-437,439,445,586,592,595-596$, 653-654, 662-663, 688-670, 698-609, 706-709; RA 21/76-77, 103-105, 131-132, 213-215, 246-247, 251-254, 364-365, 418-420, 458-459, 465-466, 494-495, 552, 558-560; RA 22/9-10, 24-25, 42-46, 88-89, 97-98, 146-148, 198, 209-210, 220-221, 237-238, 249-252, 254, 387-388, 399, 448, $572-573,583-585,587-588$; RA 23/ 4-5, 12-13, 238-240, 266-267, 359-362, 420-423, 431-432, $435-436,446-448,490-492,522,544,547-548,570-571,575,647,670-672,679-680,715-716$, $769,781-782,863-864,871,914-915,928-929,939-940,945-948,969-996,1039-1040 ; \mathrm{RA}$ 24/91-94, 123-124, 154-155, 176-177, 181-182, 248-249, 257-258, 312, 380-381, 434-436, 501-503; RA 25/65-67, 99-101, 201-203, 387-390, 461-463, 471-472, 563-565, 574-576; RA 26/306, $324-325,333-336,351-353,370-371,381,456-459,518,594-596,717-718,841-843$; RA 27/108-110, 255-256, 400-401, 408-409, 469-470, 564-568, 576-581, 892-894, 1017-1019; L. Gorizontow, Aparat urzędniczy Królestwa Polskiego w okresie rzqdów Paskiewicza, „Przegląd Historyczny" 1994, t. 85, z. 1-2. 
łamiących prawa obywatelskie. $Z$ drugiej jednak strony KRSWDiOśP wyraźnie stwierdzała konieczność realizacji przez klasę urzędniczą głównych założeń polityki państwa ${ }^{15}$.

Z kolei w 1836 r. zaszly zmiany w ,hierarchii” niektórych stanowisk zajmowanych przez urzędników administracji publicznej. W tym bowiem okresie:

a) wydalono ze służby publicznej 11 urzędników;

b) przedstawiono do pensji emerytalnej 95 wysłużonych, względnie niezdolnych do dalszego zajmowania się pracą urzędniczą osób (część urzędników występowała o przeniesienie $w$ stan spoczynku $z$ własnej inicjatywy, niekiedy zaś - najczęściej w wypadku choroby - inicjatywę podejmowały organy administracji państwowej);

c) jednocześnie KRSWDiOśP przedstawiała do tzw. dożywotniej pensji emerytalnej wdowy po zmarlych urzędnikach; ministerstwo występowało też o udzielenie bezpośredniego wsparcia finansowego dla wdów i ,dziedziców" zmarłych urzędników. W obu tych wypadkach raport KRSWDiOśP za rok 1836 nie podaje liczby osób objętych w tym czasie wspomnianą akcją;

d) wprowadzono na wakujące urzędnicze posady o charakterze płatnym 51 osób;

e) KRSWDiOśP wyznaczyła w 1836 r. 88 wójtów gmin.

Wszystkie czynności związane $\mathrm{z}$ obsadzeniem stanowisk administracji państwowej przez nowych kandydatów realizowano nadal po uprzednim utwierdzeniu ministerstwa, w drodze oceny posiadanych wiadomości o prawidłowym sprawowaniu sie $i$ sposobie myślenia kandydatów pod względem politycznym ${ }^{16}$.

Do Komisji Rządowej Spraw Wewnętrznych zgłaszali się też w $1836 \mathrm{r}$. byli polscy wojskowi (tj. żolnierze i oficerowie rozwiązanego Wojska Polskiego); 43 spośród nich KRSWDiOśP udzieliła zgodę na przeniesienie $\mathrm{z}$ trzeciej do drugiej kategorii urzędniczej ${ }^{17}$.

${ }^{15}$ II RS 104/4-5. Należy też zaznaczyć, iż poza weryfikacją klasy urzędniczej Królestwa wladze państwowe nagradzały też w początkach okresu popowstaniowego tak urzędników, jak i zwyczajnych obywateli Królestwa, którzy podczas Powstania Listopadowego popierali władze rosyjskie, czy wręcz dopuścili się zdrady narodowej. Na ten temat: RA 20/92-94, 186-189, 208-210, 430-432, 596-697, 649-650, 709; RA 21/18-19, 58-59, 253, 362-363, 422-423, 447-448, 592-593; RA 22/53-55, 142-144, 555-557; RA 23/132-133, 265, 500-501, 837-839, 864-865; RA 25/358-360, 453-455, 504-505, 517-519; RA 26/295-300, 468-470, 602-605, 716-717; RA 27/92-94, 355-356, 411-412, 605-606, 733-735, 749-750, 836-838, 851-852, 938-939, 941; DUWM 1831 - pismo Komisji Województwa z 8 XI 1831 r., DUWM 1832 - 9 I 1832 r., DUWM 1832 - pismo Komisji Województwa z 20 V 1832 r., DUWM 1833 - 19 VIII 1833 r.

16 II RS 104/255.

${ }^{17}$ II RS $104 / 256$. 
Po ogloszeniu dekretu Mikołaja I dotyczącego klasyfikacji urzędników oraz oznaczenia stosownego umundurowania dla tej grupy społecznej okazało się, iż nowe prawo nie przystaje do polskiej rzeczywistości; wiele bowiem istniejących w tym czasie urzędów nie zostało objętych klasyfikacją opracowaną w Petersburgu. Niektóre urzędy otrzymały niższą klasę od tej, jaka im się należała, chociażby ze względu na dotychczasowe miejsce i znaczenie organów administracji państwowej w ogólnym systemie hierarchicznym zarządu kraju. Stąd, w celu uzupełnienia pierwotnej klasyfikacji, KRSWDiOśP opracowała w roku 1836 projekt dotyczący wprowadzenia zmian w obowiązującej już ustawie. Następnie stosowne wnioski przekazano członkowi Komisji Rządowej, który został wyznaczony do zasiadania w Komitecie działającym pod kierownictwem Dyrektora Głównego prezydującego w KRSWDiOśP, oceniającym stan wprowadzenia w Królestwie nowej klasyfikacji urzędniczej ${ }^{18}$.

W kolejnym roku 1837 w systemie hierarchii urzędniczej Królestwa Polskiego nie zaszły znaczniejsze zmiany, natomiast w ciągu dwunastu miesięcy tego roku nominowano na posady w rządach gubernialnych oraz na terenie poszczególnych obwodów i miast 67 urzędników państwowych. W tym samym czasie nominacje otrzymało 92 wójtów gmin, zaś 152 urzędników ministerstwo przedstawilo do pensji emerytalnej ${ }^{19}$.

U schyłku lat trzydziestych XIX w. okazywało się jednak, iż postulaty polskich władz o konieczności obsadzania urzędów administracji cywilnej jedynie $w$ pelni kompetentnymi jednostkami nie znajduja zrozumienia u cesarza i jego namiestnika. W 1838 r. pojawiła się bowiem znaczna liczba poleconych przez Mikołaja I oraz Paskiewicza nominacji na kandydatów na urzędy podlegające KRSWDiOśP. Osoby te uzyskaly prawo do udzielenia im posad przed innymi kandydatami. Najczęstszymi zaś argumentami na rzecz swoistego wsparcia danej osobie były: a) bliżej zresztą nieokreślone tzw. szczególne zasługi; b) okazanie podczas powstania wierności dla „prawego rządu"; c) jeszcze bardziej enigmatyczne inne względy.

W tymże samym $1838 \mathrm{r}$. zgłoszono do KRSWDiOśP 118 tego właśnie rodzaju kandydatów do pracy $w$ agendach podległych temu ministerstwu urzędników ${ }^{20}$.

Kiedy jednak okazało się, iż wiele z protegowanych osób nie znajdowało się w tym czasie w Królestwie Polskim, wówczas władze ministerialne z gen. Szypowem na czele wyraziły troskę, że nie można było uzyskać wiarygodnych informacji o kwalifikacjach, ani o miejscu zamieszkania kandydatów. W tej sytuacji, po uzyskaniu stosownego zezwolenia ze strony feldmarszałka

\footnotetext{
${ }_{18}$ II RS 104/256-257.

${ }^{19}$ II RS 105/2.

${ }^{20}$ II RS $105 / 87-88$.
} 
Paskiewicza, wezwano - za pomocą ogłoszenia w pismach publicznych - desygnowane na urzędy w Królestwie osoby do: stawienia się w ściśle określonym terminie do prezentacji w KRSWDiOśP, oraz do nadesłania dokładnej informacji o aktualnym miejscu swego pobytu. Ministerstwo zastrzegło zarazem, iż osoby, które nie zgłoszą się na określany właśnie termin, zostaną automatycznie wykreślone $\mathrm{z}$ listy (preferowanych) kandydatów ${ }^{21}$. Zgłaszający się po opublikowaniu wspomnianego tu wezwania kandydaci mieli jednak nadal obowiązek udowodnienia w formie egzaminacyjnej, do jakiego rodzaju slużby rzqdowej korzystnie użyteczni być moga.

Ostatecznie wszyscy ze zglaszających się, wyznaczonych przez najwyższe czynniki decyzyjne, kandydatów zostali albo skierowani do zajęcia posad, względnie też - po uzyskaniu odpowiedniego zezwolenia ze strony namiestnika Królestwa - skreślono ich $\mathrm{z}$ list kandydackich. To ostatnie następowało w wypadku stwierdzenia u nich braku odpowiedniego usposobienia, ewentualnie gdy zainteresowany nie odpowiadal na publiczne wezwania, nie stawiając się $w$ terminie do biur KRSWDiOśP ${ }^{22}$.

Zaskakujące jest wypracowanie procedury, w której przy nominacjach nie podważano decyzji carskich, ale jej skuteczność uzależniano od weryfikacji przedstawionych kandydatów, szczególnie ich „konduity” i uprawnień. W $1838 \mathrm{r}$. doszło do zmian (tj. obostrzenia) przepisów nominacyjnych urzędników KRSWDiOśP (wójtów gmin). Na mocy -- co warte szczególnej uwagi - rozkazu feldmarszałka Paskiewicza z 7/19 czerwca wydano ogólne rozporządzenie, mocą którego osoby służące uprzednio $w$ byłym Wojsku Polskim, należąc tym samym do trzeciej kategorii kandydatów ubiegających się o urzędnicze posady wójtowskie (czyli o urząd wójta gminy), nie mogą być desygnowane na te stanowiska bez wcześniejszego przeniesienia ich do drugiej kategorii kandydackiej ${ }^{23}$. Takie rozporządzenie Paskiewicza było odpowiedzią na stosowaną przez polską administrację praktykę oceniania kwalifikacji desygnowanych na urzędy „,odgórnie nominowanych” kandydatów.

Ostatecznie w ciągu roku 1838 wydano nominacje na:

a) 12 wyższych urzędników administracyjnych pracujących w rządach gubernialnych oraz $w$ administracji obwodowej;

b) 27 urzędników pracujących w administracji miejskiej;

c) 69 wójtów gmin.

Zatem w 1838 r. wydano łącznie 108 nominacji urzędniczych w ramach administracji podlegającej KRSWDiOśP ${ }^{24}$.

\footnotetext{
${ }^{21}$ II RS $105 / 88$.

${ }^{22}$ II RS $105 / 89$.

${ }^{23}$ II RS $105 / 91$.

${ }^{24}$ II RS 105/91.
} 
W tym samym roku Ministerstwo ,przedstawiało” swoich urzędników, którzy mieli już wysłużoną liczbę lat, a także pozostałych po zmarłych urzędnikach członków rodzin, przeznając tym osobom:

1) pensję emerytalną - 55 przypadków;

2) udzielane na podstawie art. 22 dekretu o emeryturach cywilnych w Królestwie Polskim wsparcie na jeden rok dla wdów (oraz dzieci) pozostałych po urzędnikach i oficjalistach - 15 przypadków.

Zatem „przedstawienie" urzędników oraz ich rodzin przez KRSWDiOśP w 1838 r. zamknęlo się liczbą 70 osób $^{25}$.

Dodatkowym zagadnieniem będącym przedmiotem zainteresowania władz centralnych i ministerialnych Królestwa było rozstrzyganie różnorakich kwestii finansowych, związanych $z$ realizacją prac urzędniczych ${ }^{26}$. W $1837 \mathrm{r}$. KRSWDiOśP wydała np. rozporządzenia o przeprowadzeniu śledztw w sprawach o zaskarżenia: 97 urzędników państwowych oraz 102 wójtów gmin. Spośród tej liczby obwinionych tylko dziesięciu urzędników (tj. mniej niż $5 \%$ oskarżonych) oddalono ze służy na podstawie potwierdzenia zarzutu o nadużycie posiadanej wladzy. Inne osoby, którym udowodniono nieprawidłowości urzędnicze, podlegały różnym stopniom penalizacji: oddawano je pod sąd względnie nakazywano uiszczanie tzw. kar (opłat) porządkowych. Ogólną wytyczną postępowania KRSWDiOśP było w tym zakresie niedopuszczanie do pozostawienia wykrytego sprzeniewierzenia się urzędnika państwowego bez odpowiedniej sankcji ${ }^{27}$.

W roku 1838 rozpoznawano też sprawy o zażalenia na prace urzędników podlegających KRSWDiOśP; wnoszono je przeciwko: dwóm komisarzom obwodowym oraz 50 urzędnikom miejskim i 42 wójtom gmin. Ministerstwo rozpatrywało zatem w ciągu $1838 \mathrm{r}$. zaskarżenia napływające przeciwko 94 podlegającym tej właśnie Komisji Rządowej urzędnikom państwowym ${ }^{28}$.

Na skutek stwierdzenia nadużyć popelnionych w pracy administracyjnej $w$ roku tyn zwolniono $z$ zajmowanych stanowisk: pięciu urzędników zatrudnionych $w$ rządach gubernialnych $\mathrm{i} w$ administracji obwodowej, ponadto 17 urzędników zatrudnionych $w$ administracji miejskiej oraz dziesięciu

${ }^{25}$ II RS $105 / 92$.

${ }^{26} \mathrm{O}$ stronie finansowej funkcjonowania klasy urzędniczej Królestwa: RA 21/163-175; RA 23/210-215, 956-958; RA 24/31-34, 157-158, 267-268, 580-591, 623-630, 640-643; RA 25/12-15, 291-293, 344-346; RA 26/364-368, 913-915; DUWM 1832 - pismo z 23 XII 1831 r.; DUWM 1832 - pismo Komisji Województwa z 9 I 1832 r.; DUWM 1832 - pismo Komisji Województwa z 15 I 1832 r.; DUWM 1832 - pismo Komisji Województwa z 10 IV 1832 r.; DUWM 1833

- pismo Komisji Województwa z 29 IV $1833 \mathrm{r}$.

${ }^{27}$ II RS 105/2-3.

${ }^{28}$ II RS $105 / 92$. 
wójtów gmin. Zatem władze KRSWDiOśP zwolniły wówczas - po stwierdzeniu nieprawidłowości $w$ prowadzonej praktyce urzędniczej - 32 swoich urzędników ${ }^{29}$.

3. Na posiedzeniu Rady Administracyjnej z 4 lutego 1833 r. zauważono, iż w przeszłości: czesto sie zdarzalo, że urzędnicy byli przyjmowani do siuzby, a później odpowiadali za przewinienia, których się wcześniej $w$ innej slużbie dopuścili. W związku $\mathrm{z}$ tą konkluzją postanowiono, aby osoby wchodzace do slużby cywilnej $w$ Królestwie Polskim, albo przenoszace się z jednego Wydzialu do drugiego składały dowody $w$ pierwszym razie co do samej kwalifikacji, $w$ drugim, co do poprzedniej slużby. Nałożono na pracodawce obowiązek udzielania odchodzącemu urzędnikowi tzw. świadectwa o petnionych obowiazkach, co prawodawca uzależnił od żądania wystosowanego przez odchodzącego pracownika ${ }^{30}$.

Nowe zasady, utrudniające w praktyce przyjmowanie do pracy, thumaczono konkretną sytuacją, w której rzqd nie wie, z kim ma do czynienia i urzędnicy, którzy na zaufanie nie zasiuzyli dostaja sie do slużby i mogq uzyskać znak nieskazitelnej sluzby i pensje emerytalne, do których prawo utracili. Prawodawca tłumaczył zarazem, iż niewygodności te moga być odwrócone przez zaprowadzenie $w$ Królestwie Polskim stanów slużby urzędników w sposób, jak to $w$ Rosji ma miejsce, a mianowicie przez ustanowienie zasady, która wprowadza procedure że każdy urzędnik rozpoczynający slużbe cywilna oprócz świadectwa swej kwalifikacji obowiqzany jeszcze być ma zlożyć jeszcze tej wladzy, do której wchodzi wszelkie dostępne mu dowody uprzedniej służby.

Drugą zasadą, jaką miano wprowadzić w Królestwie, było założenie, iż przy uwolnieniu urzędnika od slużby lub onegoż przeniesienia $z$ jednego do drugiego wydzialu rzadowego wszystkie powyzej wymienione dowody maja pozostać przy tej wladzy, w której w końcu stużyl, jemu zaś ma być wydana jedynie lista stanu slużby. Ostatecznie nakazano też, aby każdy urzędnik, który otrzymal takowy stan slużby $i[\ldots]$ pragnie poświęcić sie nadal zawodowi publicznemu $w$ innym wydziale administracji, winien przedstawic taki wladzy, do której przechodzi. Nowa jego zwierzchność zostawi pomieniony stan slużby przy swoich aktach, uwalniajqc zaś nastepnie urzednika od obowiazku, wyda

29 Loc. cit.

30 II RS 23/1-2. O oskarżeniach urzędników oraz wypadkach nadużycia władzy w samych początkach okresu paskiewiczowskiego: RA 20/49-62, 653; RA 21/85-86, 274-276, 418-419; RA 22/69-70, 621-613; RA 25/506-507; RA 26/346, 347, 364-368 (szczególnie istotny casus byłego prezesa województwa podlaskiego); RA 27/314-323 (nadużycia grupy urzędników obwodu piotrkowskiego); II RS 532/399-404 (casus burmistrza Lublina), II RS 540/184, 1387, 1272, 1360, 1481; II RS 540/114, 3079; II RS 541/2273. O sprawdzaniu dotychczasowego przebiegu służby urzędniczej: RA 20/33-34, 81-82, 94-95, 340, 364, 436-437, 449-450, 688-689, 706; RA 21/131, 213, 465, 481-482; RA 22/191-192, 448, 583, 587. 
$m u$ od siebie inny stan slużby, $w$ który przepisany być ma $w$ calości pierwszy $z$ uzupetnieniem co do wszystkich powyżej wyszczególnionych okoliczności, $o$ ile takie $w$ ostatniej slużbie urzędnika mialy miejsce, niemniej $z$ wyrażeniem czasu nieczynności urzędnika, jeżeliby podobny przypadek zdarzyt się ${ }^{31}$.

Wprowadzone zasady miały obowiazywać wszystkie wladze państwowe rozważające przyjęcie do służby publicznej jakiegokolwiek pracownika, a sam Namiestnik wystapil do cesarza z zapytaniem o ewentualne uwagi dotyczące nowych rozporządzeń. Co więcej, analizując projekt Namiestnika, wszyscy członkowie Rady Administracji przedstawili zgodną opinię, iż wywód feldmarszałka doprowadzil Rade do tego przekonania, że forma, podlug której listy stanu służby urzedników ukladane sq $w$ Cesarstwie $w$ calkowitości, i bez żadnej zmiany do Królestwa wprowadzona być może.

Opierając się na tych wywodach, Rada postanowiła prosić cesarza o zgodę na wprowadzenie w Królestwie list stanów służby urzędników, zgodnie $\mathrm{z}$ zasadami istniejącymi już w Rosji. Wkrótce nadeszła odpowiedź. Dnia 25 marca 1833 r. Minister Sekretarz Stanu do Spraw Królestwa Polskiego Grabowski wystosowal odezwę oznajmującą wolę cara o wprowadzeniu w Królestwie odnośnych stanów służby, stosownie do przepisów istniejących w Cesarstwie. Logiczną konsekwencją tej odezwy było postanowienie RA, nr 24033 z dnia 23 czerwca 1833 r., nakazujące wladzom uzupełnienie wyżej wspomnianych stanów służby ${ }^{32}$.

$Z$ biegiem czasu wprowadzono zasadę rozszerzenia zakresu informacji, jaką urzędnik musiał w swoim stanie służby przekazywać. Dnia 11 kwietnia 1835 r. rosyjski Senat Rządzący wydał ukaz nakazujący podawanie w odpowiednich rubrykach formularza: jakiej religii jest urzednik, jego żona $i$ dzieci. Na tej podstawie hr. Paskiewicz (przez wypis z protokołu posiedzenia RA z 23 czerwca 1835 r.) wezwał Dyrektorów Glównych w Komisjach Rządowych oraz Kontrolera Generalnego, aby wiadomość te $w$ stanach stużby wszystkich urzędników podwladnych domieścić polecili, $i$ oznaczone wyżej rubryki [...] uzupelnili przez dodanie w nadpisach wyrazów «jakiej religii».

Rada ustosunkowała się też dokładnie do wszelkich występujących przy wypełnianiu rubryk nieporozumień; wątpliwości dotyczyły czterech kwestii: 1) zamieszczania przez urzẹdników w swoich stanach służby: stażu pracy, awansów i nagród uzyskanych w czasie Powstania Listopadowego;

2) powoływania się na kampanię wojskową odbytą pod Grochowem, Ostrołęką czy Warszawą, czyli w szeregach powstańczego Wojska Polskiego;

3) zaliczania do stażu pracy shuzby $z$ wyboru, np. posła lub deputowanego;

4) języka, w jakim powinny być wysyłane adresy do cesarza, a łącznie $\mathrm{z}$ nimi i stany służby ${ }^{33}$.

\footnotetext{
${ }^{31}$ II RS $23 / 2-3$.

${ }^{32}$ II RS $23 / 3-4$.

${ }^{33}$ II RS 23/4-6.
} 
Po przeprowadzeniu analizy tych problemów, Rada Administracyjna wydała swoje orzeczenia we wszystkich kwestiach. Przede wszystkim określono, iż slużba pelniona $w$ czasie rokoszu jest slużbq wystepna [...], przeto $w$ stanie slużby nie może być o niej mowa. Raz zwróciwszy uwage na problem uczestnictwa w Powstaniu Listopadowym, czlonkowie RA postanowili uzyskać więcej danych o ewentualnej antyrosyjskiej działalności oficjalistów państwowych. Aby otrzymać potrzebne dane, nakazano wyszczególniać informacje dotyczące ewentualnych dymisji czy pobytu w armii, przy czym stwierdzono, iż nie może być mowy o kampanii buntowniczej, ani o bitwach $w$ ciagu tejże odbytych, sugerując przeniesienie tych danych $\mathrm{z}$ rubryki mówiącej o odbytych kampaniach do informacji dodatkowych. Pozytywnie natomiast zweryfikowano umieszczanie w stanach służby okresu slużby $z$ wyboru, wskazując, iż można czynić wzmianke $i$ o petnionych przez urzednika obowiazkach posta aż do czasu wybuchu rokoszu. W końcu zadecydowano, iż stany służby mają być przedstawiane RA jak dotąd, tj. w języku polskim; motywowano swoje stanowisko stwierdzeniem, że wszystkie opisy dotychczasowej pracy są układane po polsku, a brak thumaczy rosyjskich uniemożliwia przeprowadzenie $w$ tym zakresie szerszej akcji ${ }^{34}$.

$\mathrm{Na}$ mocy postanowienia Rządu Tymczasowego z października $1831 \mathrm{r}$. wszystkie awanse $\mathrm{z}$ czasu rewolucji uznano za nieważne. Komisja Rządowa Spraw Wewnętrznych podjęła też akcję weryfikacji urzędniczych nominacji, rozpoczynając ją od zbierania potrzebnych wiadomości na ten temat, przy równoczesnej realizacji zaleceń rządowych zmierzających do określenia warunków i (następnie, po weryfikacji) potwierdzenia ewentualnego przyzwolenia na utrzymywanie posad przez sprawujących swoje obowiązki urzędników. Cel mial zostać tu osiągnięty poprzez prześledzenie jednostkowych akt personalnych. Komisja RSW, realizując otrzymane polecenia, przedstawiła zatem w maju 1832 r. do oceny Rady Administracyjnej kompletne listy personalne czynnych urzędników Królestwa Polskiego. Postanowiono, aby osoby wchodzace do slużby cywilnej $w$ Królestwie Polskim, albo przenoszace sie z jednego Wydzialu do drugiego składały dowody $w$ pierwszym razie co do samej kwalifikacji, $w$ drugim - co do poprzedniej slużby (tzw. stany służby). Weryfikacje urzędnicze trwały zresztą przez cały okres lat trzydziestych, a KRSWDiOśP wielokrotnie podkreślała konieczność realizacji głównych założeń polityki państwa przez klasę urzędniczą.

${ }^{34}$ II RS 23/4-6, 14, 19-27. Należy zaznaczyć, iż odpowiedź RA na zapytanie Paskiewicza z 23 VI 1835 r. nastąpiła dopiero na sesji tej instytucji z dnia 17 II 1837 r., a więc dopiero w okresie będącym już poza naszym zainteresowaniem. 
4. Oceniając te tendencje, należy stwierdzić, iż przyjmowanie i weryfikacja urzędników państwowych wczesnej ery paskiewiczowskiej przebiegało dość sprawnie. Realizując postulaty władz rosyjskich, wykluczono z szeregów administracji osoby nieprawomyślne, np. czynnie wspierające władze powstańcze. Jednocześnie KRSWDiOśP zdecydowanie opierała się przyjmowaniu do polskiego aparatu urzędniczego osób nie posiadających odpowiednich kompetencji. Paradoksalnie, do obrony polskości administracji i polskiego aparatu administracyjnego przyczyniło się właśnie wprowadzenie w Królestwie owych szczegółowych przepisów dotyczących samych stanów służby. 